ISSN 2392-4896 (online)

ISSN 2392-4888 (print)

Journal of Management and Development Studies Vol. 27:pp.59-87

Available online http://nasc.org.np

(C)2016Nepal Administrative Staff College

Gopi Khanal

\title{
Fiscal Decentralization and Municipal Performance in Nepal
}

Joint Secretary, Ministry of Federal Affairs and Local Development, Nepal

Email: gopikhanal@gmail.com

Accepted 15 August 2016

The literature on decentralization is inconsistent to explain the effectiveness of fiscal decentralization on local governance. Based on the descriptive data on revenue and expenditure decentralization from 51 Nepali municipalities, this study found empirically significant positive relationship between revenue decentralization and municipal performance. However, regression results showed an insignificant association between fiscal transfer and municipal overall performance. The study suggests that devolving power to tax is associated with better municipal performance than downloading expenditure responsibilities to municipalities through fiscal transfers.

Keywords: Revenue decentralization; fiscal transfer, performance measures

\section{Introduction}

Nepal began the journey of decentralized governance with the enactment of Local SelfGovernance Act (LSGA) in 1999. Earlier efforts on decentralization were driven primarily by the deconcentration where the local government bodies were considered as the administrative branches of national government. LSGA 1999 provides the legal basis for the management of local government bodies in Nepal. Currently, there are 3157 Village Development Committees (VDCs), 75 District Development Committees (DDCs), and 217 municipalities in Nepal. VDCs and municipalities are the lowest tiers of local government whereas the DDCs serve as the intermediary organization at the district level. Despite the absence of elected officials in these institutions, the Government of Nepal is allocating around 11 percent of its annual budget for these bodies (Local Bodies Fiscal Commission [LBFC], 2015). Being the proximate governance institutions at the local level, local bodies 
Fiscal Decentralization and Municipal Performance in Nepal

in Nepal have not only delivered immediate services to people but also provided an important space for local governance. With the rapid expansion of municipalities in recent years, municipalities have become the important structure of governance in Nepal.

\section{Municipal Governance in Nepal}

The history of municipal governance in Nepal dates back to the establishment of Kathmandu municipality in 1919 by Rana regime (Institute for Integrated Development Studies in Nepal, 2003). However, municipalities as the institution of urban governance began only in the early 1960s when the party-less Panchayat system (1960-1990) enacted Municipal Panchayat Act 1962 (ibid). A two-tiered system of local government was created, comprising 75 District Panchayats as the intermediary level, and Municipal and Village Panchayat as the lower levels of local government structure. Since the country was governed through centralized political and fiscal system, Panchayati system adopted administrative features of decentralization that embodied both the deconcentration and delegation approaches. The main motives behind decentralization were to promote local development and to expand central control over local politics (Lumsali, 2012). Decentralization in Panchayat did not provide much scope for the development of autonomous municipal government institutions (ibid).

The democratic governance adopted in 1990 paved the way to embark on the journey of decentralized governance in the country. As a result, Nepal enacted Local SelfGovernance Act in 1999 that embodies political, fiscal and administrative forms of decentralization. This Act and its associated regulations spell out the functional responsibilities of local bodies and provide legal foundations for them. However, local bodies in Nepal are bound to serve the people without any mandates from their elected political masters, as there has been no elected local government in place since 17 July 2002. As a consequence, there is an accountability deficit, mainly the downward accountability, at the local level.

Municipalities consist of one metropolitan corporation, 11 sub-metropolitan corporations, and 179 municipalities. There are in total 3092 municipal wards, sub-units of municipalities across the country. With the declaration of 159 municipalities in 2014 and 2015, the municipal population has increased to 42 percent of total population. Figure 1 shows the structure of municipal governance in Nepal. Ministry of Federal Affairs and 
Fiscal Decentralization and Municipal Performance in Nepal

Local Development coordinates and facilitates the local bodies. In principle, municipalities are not the administrative outfits of the central government. They have their own corporate status and with considerable levels of administrative, fiscal, and political autonomy. In practice, they have been virtually led and managed by cenre through centrally deputed bureaucrats.

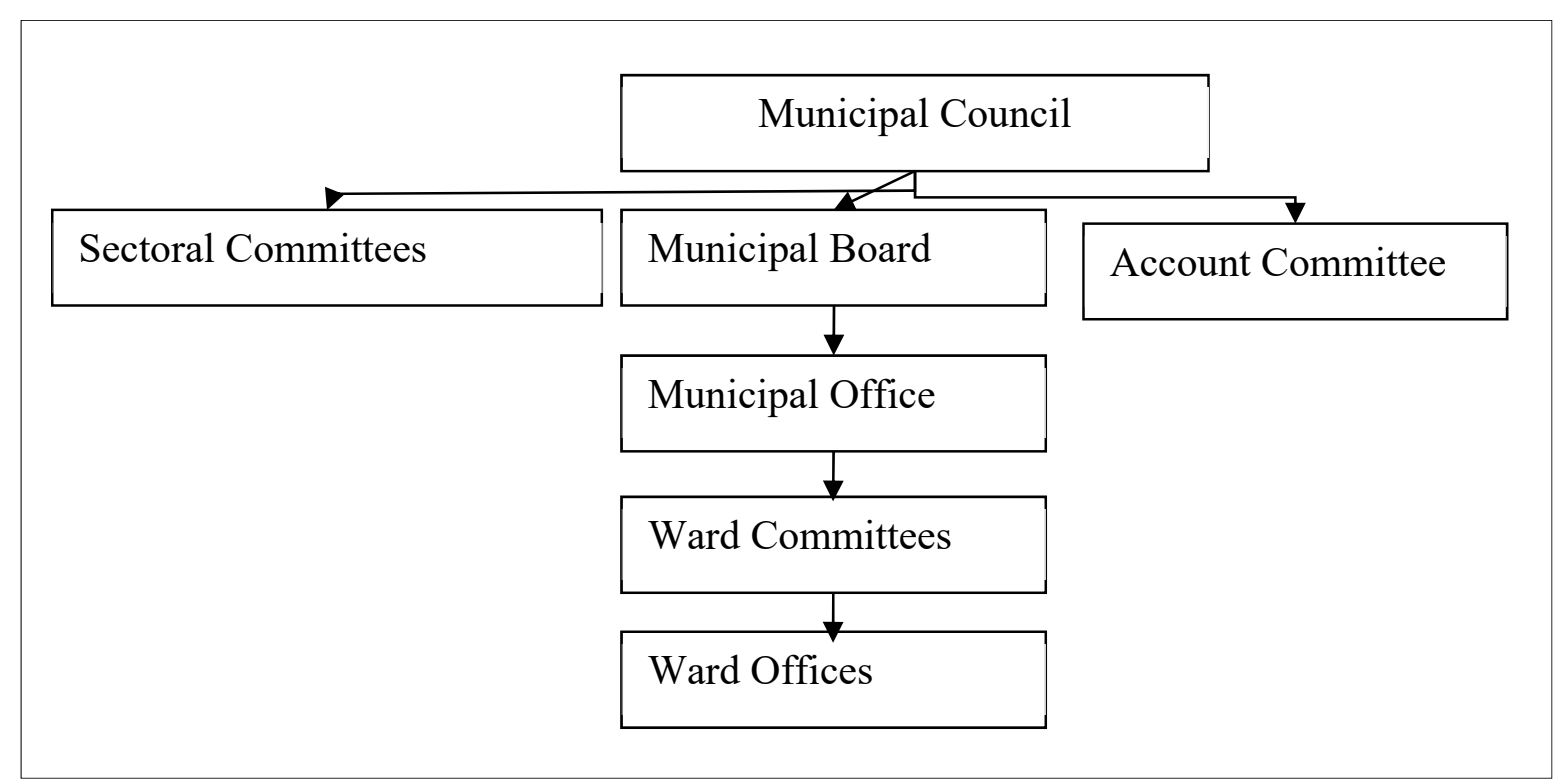

Figure 1. Municipal structure in Nepal

Municipalities in Nepal mobilize fund through own-source revenues, intergovernmental fiscal transfers, revenue sharing, external financing, and, to some extent, from local borrowing. Figure 2 depicts the budget allocation system at Nepali municipalities. Property tax, small business tax, rental tax, and fees on building permission are the major sources of their own-source revenues. For FY 2013/014, own-source revenues account for 47 per cent of total revenues in 58 old municipalities. It was around 44 percent in a previous fiscal year. However, this figure also includes the sharing of revenues on land registration on which municipalities are entitled to receive 75 percent of such sharing (LBFCS, 2015). 
Fiscal Decentralization and Municipal Performance in Nepal

Like elsewhere, municipalities in Nepal raise their own-source revenues from tax and non-tax sources. LSGA 1999 has entrusted them with the power to impose a business tax, integrated property tax, professional tax, advertisement tax, vehicle tax, entertainment tax, and house and land tax (Subedi, 2014). However, most of these taxing powers have been constrained by other central regulations. Due to its immobile nature, integrated property tax has been the main credible sources of tax revenue for many municipalities (ibid). Municipalities also raise the local revenues from different types of fees such as building permission fees, recommendation fees, parking, property valuation, and so on. Among them building permission fees have become dominant sources of non-tax income for populated urban-centric municipalities (LBFCS, 2015).

Intergovernmental fiscal transfers have been the regular and reliable source of development financing for municipalities in Nepal. Fiscal transfers to sub-national governments are important instruments to correct both the vertical and horizontal fiscal imbalances across the jurisdictions (Shah, 2007). Fiscal transfers finance around 54 percent in total expenditure of 58 municipalities in FY 2013/014 (LBFCS, 2015). Besides meeting development expenditures, these transfers are crucial to creating incentive and accountability mechanisms that affect the overall fiduciary governance at local level. Municipalities receive both the conditional and unconditional grant from the centre. Block grants are allocated to the municipality on the basis of a formula that consists of a weighted index of the population (50\%), area (10\%), weighted poverty $(25 \%)$, and weighted tax efforts (15\%) (MoFALD, 2013). Though the general-purpose block grants are a general budget support to the municipality, they are subject to some strings. Municipalities must allocate 35 per cent of capital expenditure budget for the benefits for women, children, and disadvantaged groups (ibid). They also receive sector-specific conditional grants from centre to undertake specific projects, mainly the infrastructure projects.

\section{Conceptualizing fiscal decentralization}

Decentralization is a generic term that embodies several concepts. In tandem with the evolution in thinking about governance, its concepts have changed rapidly over the past quarter of a century (Cheema \& Rondinelli, 2007). Until the early 1980s, decentralization was understood as the process of transferring authority, resources, and responsibilities of public functions from the centre to lower levels of government. By the early 1980s, as the 
Fiscal Decentralization and Municipal Performance in Nepal

notion of governance expanded from the management of government affairs within the state apparatus to manage broader public affairs, decentralization took new meanings and new forms (ibid). Today, decentralization is understood not only as the process of transferring authority within state hierarchy but also as the system of sharing power, authority, resources, and responsibilities among broader governance institutions including private and civic sectors (Drummond \& Mansoor, 2003).

Decentralization processes embody both vertical and horizontal decentralization. Vertical decentralization transfers power, authority, and resources from central government to local government. Horizontal decentralization, on the other, empowers local communities and their organizations to claim their rights and to best utilize the transferred powers for their benefits (Kauzya, 2007, p. 78). Horizontal decentralization requires the growth of active and responsible civil society as well as capable local government institutions in such a way that local governments are able to institutionalize downward accountability with the active participation of local citizens in the exercise of local governance-the formulation and execution of collective actions at the local level (ibid).

Vertical decentralization consists of deconcentration, delegation and devolution. These elements measure the degree of decentralization, i.e., the extent of local government autonomy. Deconcentration is the redistribution of public responsibilities among the national and local branches of central government by shifting the administrative workloads from central government officials located in the capital to subordinate field offices in the regions, provinces, or district (Vista-Baylon, 2001). Deconcentration does not involve a downward transfer of decision-making power and autonomy from the centre. The underlying motives behind deconcentration are to gain efficiency in service provisions or increase state control at local level, implement development projects or programmes, and/or bring the benefits of development to the citizens dispersed across the entire national territory (Blunt \& Turner, 2005). However, deconcentration can pave the way towards political decentralization as it brings government closer to the people, and provides the basic institutional foundations at the local level.

Delegation is a more extensive form of administrative decentralization. Through delegation, central government transfers the management authority and responsibility of specific public functions to specialized agencies, semi-autonomous bodies, or local governments while retaining the supervisory power at the centre (Rondinelli, 2003). Delegated agencies are vertically accountable to the centre and perform functions on behalf 


\section{Fiscal Decentralization and Municipal Performance in Nepal}

of delegating agencies. Decentralization by this approach is helpful to insulate the highpriority projects or programmes from bureaucratic red tape and political interfere. Devolution is the highest form of decentralization. Devolution transfers decision-making power, authority, resources, and responsibilities of public functions to elected local governments (Kauzya, 2007). The most important element of devolution is the presence of periodically elected local bodies. The devolved local governments generally (i) have corporate status, (ii) recruit their own staffs, (iii) occupy clear and legally recognized geographic boundaries, and (iv) raise own-source revenues (Vista-Baylon, 2001).

Decentralization is often understood through its political, administrative, and fiscal dimensions. Political decentralization entails the transfer of power to lower levels of elected governments through devolution. Broadly, decentralization is a mechanism of sharing political power among the central and local levels of governance (Nepal South Asia Centre, 1998). Administrative decentralization involves deconcentration and delegation of public functions at the local level without relinquishing central supervisory powers.

Fiscal decentralization is not a separate form of decentralization. Instead, it is financing mechanisms that underpin both the political and administrative forms of decentralization (Alam \& Scott, 2011, pp. 1-2). Horizontal decentralization moves public functions from local governments to non-state actors such as private sectors and civil society organizations through economic and civic decentralization. By economic decentralization, local governments create enabling an environment for private sectors for investment and growth through public-private dialogue and/ or public-private partnership. In civic decentralization, local governments engage local civil society organizations in the management of local affairs.

Fiscal decentralization is mainly about equipping local government with required fiscal resource to meet their expenditures. It involves the transfer of expenditure responsibilities and revenue sources from central to local government (Vista-Baylon, 2001). Subsidiarity principle is the key theoretical construct behind the fiscal decentralization. According to this principle, taxing, spending, and regulatory functions should be exercised by lower levels of government unless a convincing case can be made for assigning them to higher tiers of governments (Shah \& Shah, 2006, p. 4). Advanced by Oates (1977), the "decentralization theorem" also provides the normative economic justification for fiscal decentralization. According to this theorem, "each public service should be provided by the 
Fiscal Decentralization and Municipal Performance in Nepal

jurisdiction having control over the minimum geographic area that would internalize benefits and costs of such provision" (as citied in Subedi, 2014).

As presented in Figure 2, fiscal decentralization is commonly understood by its four pillars: (i) expenditure assignment; (ii) revenue assignment; (iii) intergovernmental fiscal transfers; and (iv) local borrowing (Boex, 2001; Litvack \& Seddon, 1999). As the first step in designing the intergovernmental relationship, expenditure assignment clearly divides responsibilities of public functions among the different tiers of government. The design of other pillars of fiscal decentralization without clear expenditure assignment would be like putting the 'cart before the horse' (Martinez-Vazquez, 2001, p. 1). There is no any hard and fast rule on the allocation of functional responsibilities among central and sub-central levels of government. The key principle to resolve this issue is the 'subsidiarity principle' which suggests that government services should be provided by lowest levels of government that are capable of providing public goods and services efficiently (Boex, 2001). Richard Musgrave, one of the pioneer public economists, provided the normative insights for intergovernmental functional assignments. He suggested that central governments are best suited for (i) the provision of public goods and services that benefit the entire country, (ii) income redistribution, and (iii) government activities that produce negative externalities among jurisdictions (Musgrave, 1959). Local governments are suitable to provide local public goods and services.

Revenue assignment is all about division of taxing powers among different orders of government. In well-designed revenue assignment system, local governments have powers to choose the tax base, assess the tax base, decide the rate, collect the tax, and retain the tax proceeds. The basic principle of revenue assignment is that local government should not be subject to unfunded mandates. The services that local governments provide should be clearly linked to the revenue sources needed to finance them (Freire \& Garzon, 2014). Division of taxing powers between national and sub-national government entities has been one of the unresolved issues in the design of intergovernmental fiscal architecture. 
Fiscal Decentralization and Municipal Performance in Nepal

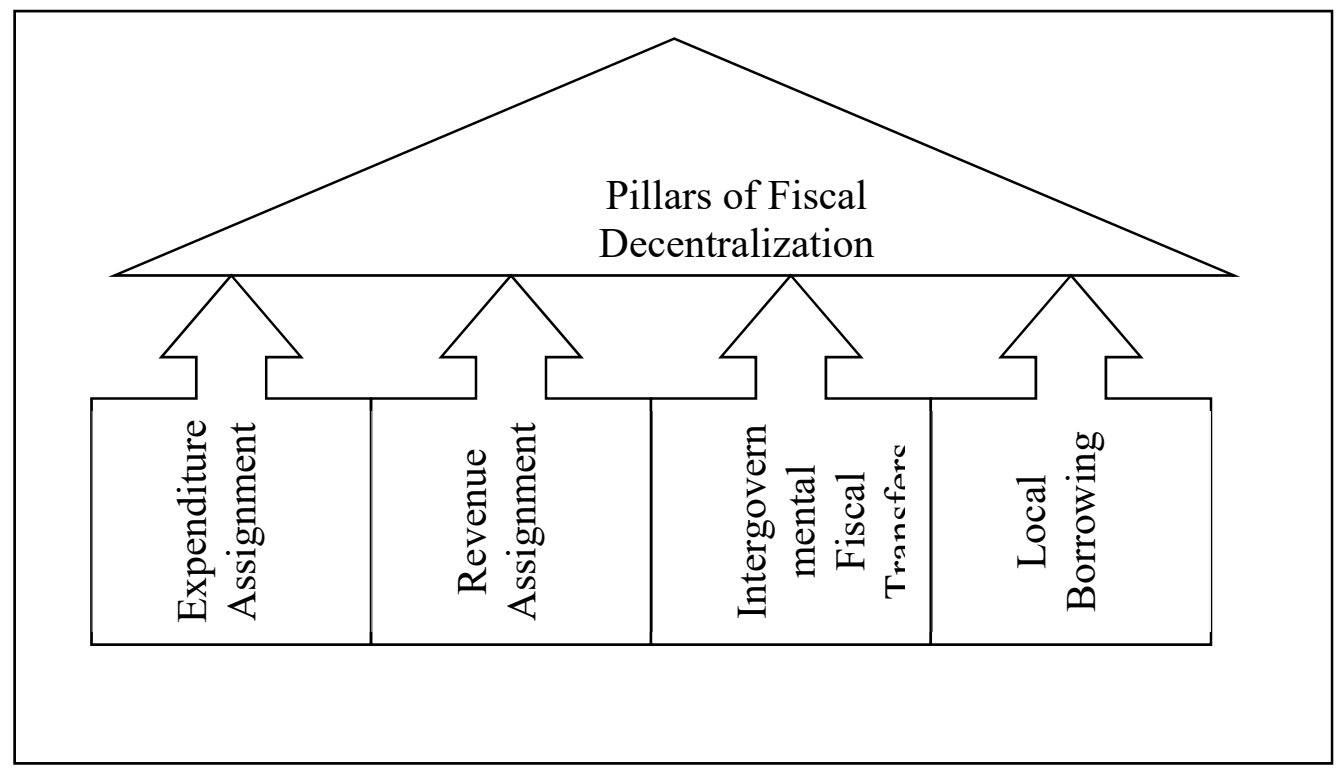

Figure 2; Pillars of fiscal decentralization (Martinez-Vazquez, 2001)

Intergovernmental fiscal transfers have been the dominant source of financing for local governments in most countries (Boadway \& Shah, 2007). Intergovernmental fiscal transfers are the main instruments to resolve the issues of vertical and horizontal fiscal gaps. Vertical fiscal gaps arise when there are differences in revenue means and expenditure needs at local governments. Among others, inappropriate assignment of responsibilities, lack of tax rooms at local levels due to heavier tax burdens imposed by the centre, and centralization of taxing powers are the main causes of such gaps (Shah, 2007). Horizontal fiscal gaps, on the other hand, arise when there are differences in the ability of individual local government to raise revenue. Intergovernmental fiscal transfers play an important role to minimize these gaps through the system of fiscal equalization (Ebel \& Muwonge, 2014). For instance, Government of Nepal is providing formula-based grants to local governments to reduce these gaps.

Municipalities play crucial roles to develop socio-economic infrastructures at the local level. For the long-term projects, they join either in financial and/or capital markets. Since borrowing is a transfer of liabilities to the future generation, it should be used only for 
Fiscal Decentralization and Municipal Performance in Nepal

capital investments that generate long-term economic benefits (Freire, 2014). However, local borrowing often invites macro-economic instability. As such, instituting local borrowing without hard budget constraints could be fiscally risky in the management of fiscal decentralization.

Fiscal decentralization is also understood by its two important measures: expenditure decentralization and revenue decentralization (OECD, 2013). Expenditure decentralization is the ratio of local government expenditure in total government expenditure. This measure indicates the fiscal importance and spending capacity of local governments in a country. However, it does not explain about the fiscal autonomy of local governments. Revenue decentralization is the ratio of local own-source revenues vis-à-vis total national revenues (Letelier, 2005)

\section{Effectiveness of fiscal decentralization}

There is no consensus among the scholars, academics and researchers on the contribution of fiscal decentralization in local governance. Instead, empirical studies on this topic have found conflicting conclusions. Classical public economists (Musgrave, 1959; Tiebout, 1956; Buchanan, 1965; Oates, 1972) argued for normative benefits of fiscal decentralization assuming the state as benevolent actor that always serves the best interests of people. However, other scholars challenge this proposition arguing that fiscal decentralization can lead to expansion of leviathan that seeks gains at the cost of larger public.

Fiscal decentralization, in general, has shown positive impact on some of the key socio-economic variables. It has generally shown positive effect on educational outcomes (Martinez Vazquez, 2011). In Bolivia, Faguet (2004) identified the supportive role of decentralization to make public investment more responsive to local needs. In Colombia, Faguet and Sanchez (2006) found the positive contribution of decentralization to improve public school enrolment. Fiscal decentralization has also shown a positive impact on human development index- a proxy index to measure the average achievement in human development (Sepulveda \& Martinez-Vazquez, 2010).

The empirical studies on the effectiveness of decentralization on local health services have shown mixed results. In Argentina, Habib et al. (2003) found that more local autonomy on revenue decentralization contributed to decrease the infant mortality rates. They also found the positive association between fiscal decentralization and human development. 


\section{Fiscal Decentralization and Municipal Performance in Nepal}

Analysing the case of highly decentralized Canadian provinces for the period of 1979-1995, Rubio (2010) identified that health services decentralization in Canada has had positive influences in improving the health of public. Applying the panel data on infant mortality rates, gross domestic product (GDP) per capita, and the share of public expenditure managed by local governments, Robalino, Picazo, and Voteberg, (2001) discovered that fiscal decentralization is consistently associated with lower mortality rates.

The empirical evidences on the impact of decentralization on poverty reduction are mixed. Some scholars (e.g., Crook \& Manor, 1998; Crook \& Sverrisson, 2001) have highlighted the positive impact of decentralization on poverty reduction. Decentralization has provided incentives to local governments in China to foster entrepreneurship and economic success (Weingast, 1995). China has been able to achieve economic growth through 'market-preserving federalism' for which local governments are the key actors in villages and township (ibid). Analyzing the China's experience of transition to a market economy, Qian and Roland (1998) also identified that fiscal decentralization induces economic competition among local governments to make economic investments. They compete with each other to attract investors into their area. Testing the panel data over the period of 1985-98 in China, Qiao, Martinez-Vazquez, \& Xu, (2008) found that fiscal decentralization has led to economic growth but at the cost of regional inequalities. In United States, Sobel et al. (2013) discovered that decentralization has supported a better business climate and faster economic growth at state level. On the contrary, a study by Abdullatif et al. (2013) found the higher costs of doing business due to higher levels of fiscal decentralization. In 2013, Development Research Group in the World Bank carried out an intensive research on the effectiveness of participatory approach of development and found that the benefits of decentralization are asymmetric. The people who benefits from decentralization tend to be the most literate (Mansuri \& Rao, 2013). The report concludes that local participation works well if projects are based on well thought-out and tested designs, facilitated by responsive center. The report argues for organic participationparticipation from self-made civic associations on free will and common aspirations in the place of induced participation implemented by bureaucracies (ibid).

Several studies from India found an inconclusive association between decentralization and local governance. For example, in a study in Indian state of West Bengal, Bardhan and Mookherjee (2006) found the intensive level of elite captures in the projects supported by local government in relation to the projects executed by non-state 
actors. Examining the data from four Indian states, Markusen (2006) found that villagers affiliated to ruling political parties at Village Panchayat were more likely to be benefited from poverty reduction schemes such as Below Poverty Line (BPL) cards.

In a cross-country empirical analysis, Martinez-Vazquez (2009) found that the level of total public sector employment opportunities in a country increases with its level of fiscal decentralization. Moreover, fiscal decentralization relocates such opportunities from centre to local. Their empirical works also showed that total public sector employment is higher in unitary countries than in federal countries. They also found that public sector employment increases with the pace of country's economic openness. These findings are critically important in Nepal as the country has embarked on the journey of federal governance and there are arguments and counter-arguments about the pros and cons of federalism.

There are limited empirical studies on effectiveness of fiscal decentralization in Nepal. Taking the case of district development committees, Devkota (2014) examined empirically about the impact of fiscal decentralization on per capita GDP of district and found positive influences of revenue and expenditure decentralization indices on per capita district GDP. The regression results were robust in this study. Subedi (2014) asserted that fiscal decentralization not only demands strong supply-driven initiatives but also depends on the level of awareness in society. He also urged the need of elected representatives for functioning decentralized governance in Nepal.

\section{Data and methods}

The target population of this study is the old 58 municipalities. Though there are 217 municipalities in Nepal, this study does not take into account the recently declared new 159 municipalities. These new municipalities have not yet the basic fiscal and administrative foundations to consider them as the competent institutions for this study. These new municipalities are still struggling to equip them with required institutional infrastructure. They do not have the basic data set required for empirical analysis. Understanding nature of local governance needs the thorough analysis of trends on municipal performance. This study is thus bound to select 58 old municipalities for the population.

This study draws on the data produced by Local Body Fiscal Commission. The dependent variable of this study is the average scores on performance measures for fiscal year 2007/08- 2013/014. The average per capita municipal own source revenue and fiscal 
Fiscal Decentralization and Municipal Performance in Nepal

transfer for the period of fiscal year 2007/08- 2013/014 have been taken as independent variables. LBFC assesses the yearly performance of old municipalities. There are altogether 40 indicators under five broader functional areas of municipal performance which are: (i) local governance, (ii) financial resources mobilization and management, (iii) planning and program management, (iv) organization and human resources development, and (v) basic urban service management. The 40 municipal performance indicators are shown in Annex A.

For the empirical purpose, this study has followed the stratified random sampling. In stratified random sampling, the strata are formed based on the common characteristics of members and random sampling is done to proportionately represent the stratum. Given the diverse nature of municipalities in fiscal behaviour and its size, this study has followed the random sampling techniques. Municipalities were divided into Hill and Terai. There were 32 municipalities located at Terai and 26 in the hills. These municipalities were further clustered according to population and average scores achieved in performance measures for the period of FY 2007/08 to FY 2010/013. Then samples were selected randomly using random number table each cluster (see Annex B for sampling plan).

Yamane (1967) sampling technique was used to determine the size of the sample.

$N_{0}=N /\left(1+N \times \alpha^{2}\right)$

Where,

$\mathrm{N}_{0}=$ Number of sample size

$\mathrm{N}$ (Total target population $)=58$

$\alpha$ (Level of significance $)=0.05$

$\mathrm{N}_{0}=58 /\left(1+58 \times .05^{2)}\right.$

$\mathrm{N}_{0}=51$

\section{Data analysis and findings}

In order to examine the relationship of scores on performance measures with municipal revenue decentralization and fiscal transfer, following research hypothesis and the regression model is set. 
Fiscal Decentralization and Municipal Performance in Nepal

$\mathrm{H}_{1}=$ There is significant relationship between scores on performance measures, municipal revenue decentralization, and fiscal transfer.

$Y=a+\beta_{1} R D_{1}+\beta_{2} F T_{1}+e 1$

Where,

$Y=$ Dependent variable, i.e., average scores on performance measures for fiscal year 2007/08- 2013/014 of sample 51 municipalities

$R D_{1}=$ Revenue decentralization, i.e., average per capita municipal revenue of 51 sample municipalities for the period of fiscal year 2007/08-2013/014

$F T_{1}=$ Fiscal transfer i.e., average per capita intergovernmental fiscal transfer for 51 sample municipalities for the period of fiscal year 2007/08- 2013/014

A linear regression model was performed to determine if the level of revenue decentralization and fiscal transfer could predict the level of municipal performance. The alternative hypotheses tested were that the regression coefficient was equal to 0 . The data were undergone econometric analysis to know whether they follow the regression assumptions and found theoretically plausible.

Testing the assumptions: Regression analysis is one of the widely used statistical tools in social science research to understand the relationship of a set of independent variables to a dependent variable (Orme \& Orme, 2009). Social science researchers use this method to make a prediction of the dependent variable based on the independent variables (ibid). Multiple regressions, however, must meet some assumptions to provide the valid results. Among others, the most common assumptions are the assumption of linearity, the absence of multicollinearity, the normality of data, and absence of autocorrelation (Sreejech, Mohapatra, \& Anusree, 2014). Checking these assumptions are fundamental before conducting the correlation and regression analysis.

A statistical test of normality: Regression and correlation analysis assume that residuals are approximately normally distributed. This study has checked this assumption by conducting Shapiro-Wlik (S/W) test and Kolmogorov-Smironov $(\mathrm{K} / \mathrm{S})$ test. It has also tested this assumption by making the visual inspections of a histogram and a normal quantile-quantile (Q-Q) plot. It first tested the normality of errors using $\mathrm{S} / \mathrm{W}$ and $\mathrm{K} / \mathrm{S}$ tests. Own-source 
Fiscal Decentralization and Municipal Performance in Nepal

revenue measures the extent of revenue decentralization whereas fiscal transfer explains the degree of transfer dependency. It tested following null hypothesis for this purpose:

$H_{0}=$ the data on revenue decentralization and fiscal transfer is normally distributed.

Alpha level was set at .05. As per the $\mathrm{S} / \mathrm{W}$ and $\mathrm{K} / \mathrm{S}$ tests, the null hypothesis that data are approximately normally distributed is rejected if the p-value is less than chosen alpha level. In this case, if the $p$-value is greater than alpha level $(p>0.05)$, then, data are assumed to be normally distributed (Barton \& Peat, 2015). Normality test results of data are shown in Table 1. To assess the goodness of fit to a normal distribution, Shapiro-Wilk test was used because this test is more powerful when the sample size is small (Marques de Sa, 2007). Kolmogorov-Smirnov test was used for checking the normality of data because the sample size is 51 , which is greater than the minimum required sample size for this test, which is 50 .

Table 1: Shapiro-Wilk and Kolmogorov-Smirnov tests of normality

\begin{tabular}{lllllll}
\hline & \multicolumn{3}{c}{ Kolmogorov- } & \multicolumn{3}{c}{ Shapiro-Wilk } \\
& \multicolumn{1}{c}{ Smirnov $(\mathrm{K} / \mathrm{S})^{*}$} & \multicolumn{3}{c}{$(\mathrm{S} / \mathrm{W})$} \\
\hline Der capita own revenue & .154 & Df & Sig. & W & Df & Sig. \\
Per capita fiscal transfer & .122 & 51 & .004 & .844 & 51 & .000 \\
Performance scores & .104 & 51 & .055 & .876 & 51 & .000 \\
\hline & & .200 & .968 & 51 & .069 \\
\hline
\end{tabular}

Note: D refers to the test statistic for $K / S$ test and $W$ is the test statistic for $S / W$ test (Flynn, 2010; Field, 2009). Df is the degree of freedom and Sig. is a level of significance. *With Lilliefors correction for parametric tests.

In Table 1 , the $\mathrm{p}$-value of $\mathrm{S} / \mathrm{W}$ test for revenue decentralization and fiscal transfer variables is .000 , which is less than set alpha level $(p<.05)$. The data on per capita amount of own-source revenue, $\mathrm{W}(51)=.844, \mathrm{p}=.000$ and per capita fiscal transfer, $\mathrm{W}(51)=.876$, $\mathrm{p}=.000$ deviated significantly from normal. However, data on municipal performance scores $\mathrm{W}(51)=.968, \mathrm{p}=.069$ did not deviate significantly from normal. Table 1 also shows the test statistics of Kolmogorov-Smirnov test with Lillifers significance correction. Lillifers significance correction makes this test a little less conservative. The data on fiscal transfer and municipal performance passed the $\mathrm{K} / \mathrm{S}$ tests of normality. The data on revenue 
Fiscal Decentralization and Municipal Performance in Nepal

decentralization could not pass the K/S test. Similarly, the data on fiscal transfer did not pass the $\mathrm{S} / \mathrm{W}$ test

In this respect, the null hypothesis that data are normally distributed is rejected for fiscal transfer and revenue decentralization. The data distribution of these variables could not meet one of the assumptions of multiple regressions. Boslaugh and Watters (2013) explains that normality of a given data set can be improved by applying either logarithmic transformation or the inverse transformation, or the square root transformation. All of these data transformation methods change the measuring scale on the horizontal axis of a histogram but the new variable is mathematically equivalent to the original variable. A natural $\log$ was taken to improve the normality of data on fiscal transfer and revenue decentralization. Independent variable meeting the normality criteria in $\mathrm{S} / \mathrm{W}$ test and $\mathrm{K} / \mathrm{W}$ test $(p>0.05)$ was retained in the model.

Table 2 displays the statistical packages for social sciences (SPSS) S/W test output of normality test on revenue decentralization and fiscal transfer data on natural logtransformed data. It shows that the p-values for revenue decentralization and fiscal transfer are greater than chosen alpha level $(.05<0.74$ and.076). It is also supported by $\mathrm{K} / \mathrm{S}$ test $(.05<0.20)$. The null hypothesis that data on municipal performance and natural log transformed data on fiscal transfer and revenue decentralization is approximately normally distributed are accepted (Shapiro \& Wilk, 1965). New data set allow conducting the multiple regressions. Now these data meet both the K/S test and S/W test of normality.

Table 2: Tests of normality using $\mathrm{S} / \mathrm{W}$ and $\mathrm{K} / \mathrm{S}$ tests

\begin{tabular}{lcccccc}
\hline & \multicolumn{3}{c}{ Kolmogorov-Smirnov } & \multicolumn{3}{c}{ Shapiro-Wilk Test } \\
\cline { 2 - 7 } & Test & & & & & \\
\hline Revenue decentralization & .086 & 51 & 200 & .985 & 51 & .741 \\
Fiscal transfer & .087 & 51 & .200 & .959 & 51 & .076 \\
\hline
\end{tabular}

Note: The data on revenue decentralization and fiscal transfer are transformed by using natural log transformation

Testing assumption of multicollinearity: Another important assumption of multiple regression statistics is that the independent variables that are used to explain the value of the dependent variable should be reasonably independent of each other (Barton \& Peat, 2015). 
Fiscal Decentralization and Municipal Performance in Nepal

Multicollinearity occurs when two or more independent variables in a multiple regression models are highly correlated to each other resulting in unreliable results. If we have the multicollinearity between independent variables, it is also difficult to measure the effect of each independent variable on the dependent variable. There are statistical techniques to know whether the multicollinearity is high enough to cause problems. A simple rule of thumb is that multicollinearity might be a potential problem if the sample correlation coefficient or $r$ exceeds 0.7 for any two of the independent variables (Anderson, Sweeney, Williams, Camm, \& Cochran, 2014). Pearson correlation test between revenue decentralization and fiscal transfer on SPPS was conducted. Table 3 displays the results.

Table 3: Multicollinearity test $(\mathrm{n}=51)$

\begin{tabular}{llcc}
\hline & Fiscal transfer & $\begin{array}{l}\text { Revenue } \\
\text { decentralization }\end{array}$ \\
\hline Fiscal transfer & Pearson Correlation & - & .009 \\
& Sig. (2-tailed) & & .953 \\
Revenue decentralization & Pearson Correlation & .009 & - \\
\hline
\end{tabular}

Table 3 illustrates that the Pearson's Product-Moment correlation between revenue decentralization and fiscal transfer is .009. Since this value is less than our threshold of .70 and statistically insignificant, we can conclude that multicollinearity does not exist between these independent variables. This data set meets the assumption of low level of multicollinearity between independent variables.

Testing linearity assumption: All the variables of my data set meet the assumptions of multicollinearity and normality. I then tested the linearity assumption before conducting the multiple regression to meet the criteria of regression analysis. Another assumption of multiple regression analysis is that there should be a linear relationship between dependent and independent variables. This means that the mean values of the outcome variable for each increment of the predictors lie along a straight line (Field, 2009, p. 221). As presented in Table 4, I checked the linearity relationship between level municipal performance and fiscal decentralization on using Pearson's correlation. Table 4 displays the result. 
Fiscal Decentralization and Municipal Performance in Nepal

Table 4: Test of linearity $(\mathrm{n}=51)$

\begin{tabular}{|c|c|c|c|}
\hline & & $\begin{array}{c}\text { Revenue } \\
\text { decentralization }\end{array}$ & Fiscal transfer \\
\hline Level of municipal & $\begin{array}{l}\text { Pearson } \\
\text { Correlation }\end{array}$ & .283 & .083 \\
\hline performance & Sig. (2-tailed) & .022 & .282 \\
\hline
\end{tabular}

The correlation is significant at 0.05 alpha levels.

From Table 4, we can find that there is moderately positive relationship between own-source revenue and level of municipal performance $(\mathrm{r}=.283)$. This relationship is significant at .05 alpha level because the p-value is less than alpha level. The correlation between fiscal transfer level of municipal performance weak and positive $(\mathrm{r}=.083)$ but insignificant $(\mathrm{p}>.05)$. Only the level of revenue decentralization as measured in average per capita revenue has a significant linear relationship with the dependent variable and fits with the regression model.

Correlation analysis between the level of municipal performance and fiscal decentralization: For examining the relationship between municipal performance and fiscal decentralization, Pearson correlation was calculated. Preliminary investigations were performed to ensure that there was no violation of the assumption of normality and linearity. The correlation results presented in Table 4 indicates a statistically significant positive relationship between the level of municipal performance and per capita local own revenue at municipality $(r=.283, \rho=.022)$. There is enough evidence to claim that positive correlation exists in population though this relationship is moderate. However, there is no any statistically significant relationship between the level of municipal performance and fiscal transfer $(r=.083, \rho=.282)$.

Based on the Pearson correlation results we can conclude that there is a meaningful relationship between municipal performance and per capita amount of own-source revenue. It means that there is statistically significant relationship between revenue decentralization and municipal performance. As such, the alternative hypothesis in relation to revenue decentralization and municipal performance is accepted. This study, hence, empirically claims that there is statistically significant positive, albeit moderate, relationship between 
Fiscal Decentralization and Municipal Performance in Nepal

revenue decentralization and municipal performance. This also shows that the effect accounts for about 8 percent of the total variance. According to Cohen (1992), this is a small size effect. The alternative hypothesis in relation to the relationship between fiscal transfer is rejected. In this respect, this study empirically concludes that there are no statistically significant evidences to suggest that correlation exists between fiscal transfer and municipal performance in population. The positive correlation value of .083 has occurred just because of chance.

The finding of this study supports the previous empirical study. For instance, using the cross-country data up to 75 countries De Mello and Barenstein (2001) found the positive association between tax decentralization and quality of governance provided that the share of local to national expenditure is relatively low.

Regression analysis to predict the relationship between municipal own-source revenue and municipal performance: Since the relationship between fiscal transfer and municipal performance is statistically insignificant, this study restructures the previous model using simple linear regression model. The new regression equation is as follows:

$\mathrm{H}_{1:} \hat{Y}_{1}=a+\beta_{1} R D_{1}+e_{1}$

Where,

$\mathrm{H}_{1}$ : There is meaningful relationship between municipal performance and revenue decentralization,

$\hat{Y}_{1}=$ Level of municipal performance

$R D_{1}=$ Level of revenue decentralization as measured in per-capita local own-sourced revenue

After meeting all the criteria, linear regression was conducted and found following SPSS output:

Table 5: Summary of overall multiple regression model

\begin{tabular}{llllllllll}
\hline $\mathrm{R}$ & $\mathrm{R}$ & Adjusted & Std. Error of & $\mathrm{R}$ Square & $\mathrm{F}$ & $\mathrm{df}$ & $\mathrm{df}$ & Sig. $\mathrm{F}$ \\
& Square & R Square & the Estimate & Change & Change & 1 & 2 & Change \\
.283 & .080 & .061 & 9.46645 & 0.08 & 4.276 & 1 & 49 & .044 \\
\hline
\end{tabular}

Note: Revenue decentralization is the predictor variable. 
Fiscal Decentralization and Municipal Performance in Nepal

In the model presented in Table 5, we can find that the value of correlation coefficient between the predictor variable, i.e., the level municipal performance and the outcome variable, i.e., the level of revenue decentralization is .283. This indicates that there is neither high nor very low level of association between these two variables. The coefficient of determination $\left(\mathrm{R}^{2)}\right.$ is a measure of how much of the variability in the dependent variable is explained by independent variables. In this model, $R^{2=} .061$. We can infer that only the 6.10 $\%$ variation in scores of municipal performance could be explained by the amount of municipal own source revenues. Though the model prediction weak, it is statically significant. We can assume that there are also other important factors that responsible for improving the municipal performance. Transferring revenue-generating power is not sufficient to improve the municipal performance.

Analysis of variance (ANOVA) is devised using F-statistics to test whether the model is significantly better at predicting the level of municipal performance through revenue decentralization. Table 6 displays the SPSS output on ANOVA.

Table 6: Analysis of variance source

\begin{tabular}{lllllc}
\hline Model & Sum of Squares & Df & Mean Square & F & Sig. \\
Regression & 383.146 & 1 & 383.146 & 4.276 & .044 \\
Residual & 4391.074 & 49 & 89.614 & & \\
\hline
\end{tabular}

The ANOVA results presented in Table 6 indicate the regression model is significant $(p<0.05, F=4.276)$. It means that there is a significant relationship between the level of municipal performance and level of revenue decentralization. As such, our research hypothesis that there is meaningful relationship between the level of municipal performance and revenue decentralization is accepted. We can build the regression model of prediction based on the SPSS output provided in Table 6. After assessing the overall fit of the model, I look in the individual parameters' t-value in Table 7 for testing whether the regression coefficients are individually equal to zero. If this is the case, the parameter is insignificant (Mooi \& Sarstedt, 2011). In the model presented in Table 7, both variables are significant as they have $\mathrm{p} \leq .05$. From the standardized coefficient column, we can find that level of 
Fiscal Decentralization and Municipal Performance in Nepal

revenue decentralization is significantly and positively related to performance measures. This means that more the level of revenue autonomy, better the municipal performance. However, revenue decentralization can contribute only about 8 per cent in improving municipal performance.

Table 7: Estimated regression coefficient

\begin{tabular}{|c|c|c|c|c|c|}
\hline \multirow[t]{2}{*}{ Model } & \multicolumn{2}{|c|}{ Unstandardized coefficients } & \multirow{2}{*}{$\begin{array}{r}\begin{array}{l}\text { Standardized } \\
\text { coefficients }\end{array} \\
\text { Beta }\end{array}$} & \multirow[t]{2}{*}{$\mathrm{t}$} & \multirow[t]{2}{*}{ Sig. } \\
\hline & $\mathrm{B}$ & $\begin{array}{l}\text { Std. } \\
\text { error }\end{array}$ & & & \\
\hline (Constant) & 35.00 & 13.60 & & 2.57 & .013 \\
\hline $\begin{array}{l}\text { Revenue } \\
\text { decentralizatio } \\
n\end{array}$ & 5.00 & 2.42 & .28 & 2.07 & .044 \\
\hline
\end{tabular}

From the unstandardized coefficient column presented in Table 7, we can build the following regression model:

Level of municipal performance $\left(\hat{Y}_{1}\right)=35+[5 \times 10 g$ natural of level of revenue decentralization) $]+\mathrm{e}$

Where,

Level of municipal performance is the scores on performance measures. Thirty-five is the predicted scores on performance measures when level of revenue decentralization has a zero value; 5 is the slope of the regression line, which is the coefficient for the level of revenue decentralization. This means that for every one-rupee log natural increase in revenue decentralization, predicted level municipal performance is increased by 5 rupees in per capita.

The regression equation states that the level of municipal performance in municipalities varies because of differences in local own-source revenue, but also because of random factors, represented by error terms (e). We can say that there are many factors that affect the level of municipal performance. The error term bundles up all the random 
Fiscal Decentralization and Municipal Performance in Nepal

factors that affect the scores of municipal performance in a haphazard and unsystematic way (Argyrous, 2011). This analysis shows that there is a positive relationship between the level of municipal performance and revenue decentralization. This relationship is statistically significant but not very strong. The variation in own-source revenue does moderately predict the level of municipal performance. The coefficient of determination is low $\left(\mathrm{R}^{2}=.08\right)$ which means that there are many other factors that affect the municipal performance. Not all the data points lie right on the regression line.

\section{Conclusion}

A multiple linear regression was conducted to predict the level of municipal performance based upon the per capita amount of fiscal transfer and own-source revenue. Preliminary analyses were performed to ensure the assumption of linearity, multicollinearity, normality, and absence of autocorrelation. The data on fiscal transfer could not meet the assumption of linearity. Hence, a simple linear regression was conducted to predict the level of municipal performance based upon the level of own-source revenue.

A significant regression equation was found $(\mathrm{F}(1,49),=4.28, \rho=.044)$, with an $\mathrm{R}^{2}$ of .08. Municipal predicted level of performance is equal to $35+(5 \times \log$ natural per capita amount of own-source revenue). The level of municipal performance is measured by the average per municipal performance on performance measures for the period of FY 2007/08 to FY 2013/014 for 51 sampled municipalities. Revenue decentralization is the significant predictor performance measures.

The first research hypothesis that there is a meaningful relationship between revenue decentralization and municipal performance is accepted at 0.05 alpha level. However, the second hypothesis that there is a significant relationship between fiscal transfer and municipal performance is rejected at .05 alpha level. This finding has multiple policy implications in erecting the appropriate intergovernmental fiscal architecture in the days ahead. Revenue decentralization with more taxing power to local government is worthwhile in improving the municipal performance. However, revenue decentralization alone could not contribute much to improve the overall municipal performance. Fiscal power alone is not sufficient to improve municipal performance. Balancing the political, administrative, and fiscal measures are critically important for the effectiveness of municipalities. 
Fiscal Decentralization and Municipal Performance in Nepal

\section{References}

Alam, M., \& Scott, Z. (2011). Resource guide on decentralization and local government. London: Commonwealth Secretariat.

Anderson, D., Sweeney, D., Williams, T., Camm, J., \& Cochran, J. (2014). Statistics for business and economics (12th ed.). Stamford, CT: Cengage Learning.

Argyrous, G. (2011). Statistics for research: With a guide to SPSS. New Delhi: Sage Publications India Pvt. Ltd.

Bardhan, P., \& Mookherjee, D. (2000). Capture and governance at local and natioal levels. American Economic Review. 90 (2), 135-139.

Blunt, P., \& Turner, M. (2005). Decentralization, democracy and development in a postconflict society : Commune councils in Cambodia. (25), 75-87.

Blunt, P., \& Turner, M. (2007). Decentralization, deconcentration, and poverty reduction in the Asia Pacific. In G. Cheema, \& D. A. Rondinelli (Eds.), Decentralizing governance: Emerging concepts and practices (pp. 115-130). Washington, D.C.: Ash Institute for Democratic Governance and Innovation, Havard University.

Boadway, R., \& Shah, A. (2007). Overview. In R. Boadway, \& A. Shah (Eds.), Intergovernmental fiscal transfers: Principles and practice (pp. XXVII-XLII). Washington, D.C.: The World Bank.

Boex, J. (2001). An introductory overview of intergovernmetnal fiscal relations. Atlanta: Gerogia State University, Andrew Young School of Policy Study

Boslaugh, S., \& Watters, P. A. (2013). Statistics in a nutshell: A desktop quick referecne. Sebastopol, CA: O’Reilly Media Inc.

Barton, B., \& Peat, J. (2015). Medical statistics (2nd ed.). Oxford, United Kingdom: John Wiley \& Sons Ltd.

Buchanan, J. (1965). An economic theory of clubs. Economics (32), 1-14.

Cohen, J. (1992). A power primer. Psychological Bulletin, 112 (1), 0033-2909.

Crook, R. C., \& Manor, J. (1998). Democracy and decentralization in South Asia and West Africa: Participation, accountability and performance. Cambridge: Cambridge University.

Crook, R. C., \& Sverrisson, A. S. (2001). Decentralization and poverty alleviation in developing countries: A comparative analysis or is West Bengal unique? Brighton, UK: Instutute of Development Studies. 
Fiscal Decentralization and Municipal Performance in Nepal

De Mello, L., \& Barenstein, M. (2001). Fiscal decentralization and governance: A crosscountry analysis. IMF Working Paper Series , 01 (71), 1-131.

Devkota , K. L. (2014). Impact of fiscal decentralization on economic growth in the districts of Nepal . International Centre for Public Policy Working Paper 14-20. Georgia : Andrew Young School of Policy Studies: Georgia State University.

Drummond, P., \& Mansoor, A. (2003). Macroeconomic management and the devolution of fiscal power. Emerging Markets Finance and Trade , 39 (1), 63-82.

Ebel, R. D., \& Muwonge, A. (2014). Intergovernmental finances in a decentralized world. In C. Farvacque-Vitkovic, \& M. Kopayni (Eds.), Municipal finances: A handbook for local governments (pp. 1-40). Washington, D.C.: The World Bank.

Faguet, J. P. (2004). Does decentralization increase government responsiveness to local needs?: Evidence from Bolivia. Journal of Public Economics , 88 (3-4), 867-893.

Faguet, J.-P., \& Sanchez, F. (2006). Decentralization and access to social services in Colombia. Center for Latin American Studies. Berkeley, CA: University of California.

Field, A. (2009). Discovering statistics using SPSS. London: Sage Publications Ltd.

Flynn, M. R. (2010). Analysis of censored exposure data by constrained maximization of Shapiro-Wilk W statistic. The Annals of Occupational Hygiene , 54 (3), 263-271.

Freire, M. E. (2014). Managing external resources. In C. Farvacque-Vitkovic, \& M. Kopanyi (Eds.), Municipal finances : A handbook for local governments (pp. 325-378). Washington D.C.: The World Bank.

Freire, M. E., \& Garzon, H. (2014). Managing local revenues. In C. Farvacque-Vitkovic, \& M. Kopanyi (Eds.), Municipal finances: A handbok for lcoal governance (pp. 147214). Washington, D.C.: The World Bank.

Habibi, N., Huang, C., Miranda, D., Murillo, V., Ranis, G., Sarkar, M., et al. (2003). Decentrallization and human development in Argentina. Journal of Human Development, 4 (1), 73-101.

Institute for Integrated Development Studies in Nepal. (2003). Public effortson decentralization in Nepal (Vol. 1). Kathmandu: Institute for Integrated Development Studies in Nepal.

Kauzya, J.-M. (2007). Political decentralization in Africa: Experiences of Uganada, Rawanda, and South Africa. In G. Cheema, \& D. A. Rondinelli (Eds.), 
Fiscal Decentralization and Municipal Performance in Nepal

Decentralizing governance: Emerging concepts and practices (pp. 75-211). Washington, D.C.: Ash Institute for Governance and Innovation, Harvard University. Letelier, L. S. (2005). Explaining fiscal decentralization. Public Finance Review , 33 (2), 155-183.

Litvack, J., \& Seddon, J. (Eds.). (1999). Decentralization briefing notes. Washington, D.C.: World Bank Institute.

Local Bodies Fiscal Commission Secretariat. (2015). Financial statement anaysis of local bodies. Kathmandu: Local Bodies Fiscal Commission Secretariat.

Lumsali , R. R. (2012). local service delivery and decentralization in Nepal. In S. Acharya, K. Yatru, \& J. Ban (Eds.), Local governance in Nepal (pp. 17-42). Kathmandu: MIREST Nepal.

Mansuri, G., \& Rao, V. (2013). Localizing development:Does participation work? Washington D.C. : The World Bank.

Markussen, T. (2006). Inequality and party capture: Theory and evidence from South India. Discussion Paper, University of Copenhagen, Department of Economics, Copenhagen.

Marques de Sa, J. P. (2007). Applied statistics: Using spss, statistica, matilab and r (2nd ed.). Heildelberg: Springer-Verlag Berlin Heildelberg.

Martinez-Vazquez. (2001). Intergovernmental fiscal relations and the assignment of expenditure responsibilities. Georgia: Andrew Young School of Policy Studies, Georgia State University.

Martinez-Vazquez, J., \& Yao, M.-H. (2009). Fiscal decentralization and public sector employment . Public Finance Review , 37 (5), 539-571.

Martinez-Vazquez, J. (2011). The impact of fiscal decentralization: Issues in theory and challenge in practice. Manila: Asian Development Bank.

Martinez-Vazquez, J., Lago-Penas, S., \& Sacchi, A. (2015). The impact of fiscal decentralization: A survey. Georgia: Andrew Young School of Public Policy, Gerogia State University.

Ministry of Federal Affairs and Local Development . (2015). Annual progress report for fiscal year 2014/015. Kathmandu: Ministry of Federal Affairs and Local Development.

Ministry of Urban Development. (2015). National urban development strategy 2015. Kathmandu: United Nations Human Settlements Programme. 
Fiscal Decentralization and Municipal Performance in Nepal

Mooi, E., \& Sarstedt, M. (2011). A concise guide to marketing research: The process, data and methods using IBM spss statistics. Berlin: Springer-Verlag Berline Heidelberg.

Musgrave, R. A. (1959). The theory of public finance . New York: McGraw Hill.

Muwonge, A., \& Ebel, R. D. (2014). Intergovernmental finances in a decentralized world. In C. Farvacque-Vitkovic, \& M. Kopanyi (Eds.), Municipal finances: A handbook for local governments (pp. 1-40). Washington D.C.: The World Bank.

Nepal South Asia Centre. (1998). Nepal human development report 1998. Kathmandu: Nepal South Asia Centre.

Oates, W. E. (1977). The Political economy of fiscal federalism. Lexington, MA: Lexington Books.

Organization for Economic Cooperation and Development/Korea Institute of Public Finance. (2013). Measuring fiscal decentralization: Concepts and policies. Paris: OECD Publishing.

Orme, J. G., \& Orme, T. C. (2009). Multiple regression with discrete dependent variables . Oxford: Oxford University Press.

Qian, Y., \& Roland, G. (1998). Federalism and the soft budget constraint. American Economic Review , 88 (5), 1143-1162.

Qiao, B., Martinez-Vazquez, J., \& Xu, Y. (2008). The trade-off between growth and equity in decentralization policy: China's experience. Journal of Development Economics , 86 (1), 112-128.

Robalino, D. A., Picazo, O., \& Voteberg, A. (2001). Does fiscal decentralizationimprove health outcomes? Evidence from a coross-country analysis. World Bank Policy Research Working Paper Series 2565.

Rondinelli, D. A. (2003). Promoting national competitiveness in a globalizing economy: The state's changing roles. In D. A. Rondinelli, \& G. Cheema (Eds.), Reinventing government for thr twenty-first century: State capacity in a globalizing society (pp. 33-60). Bloomfield: Kumarian Press, Inc.

Rubio, D. J. (2010). The impact of decentralization of health services on health outcomes: Evidence from Canada. Applied Economics , 43 (26), 3907-3917.

Shah, A. (2007). Introduction: Principles of fiscal federalism. In A. Shah (Ed.), The practice of fiscal federalism: Comparative perspectives. 3-42: McGills-Queen's University Press. 
Fiscal Decentralization and Municipal Performance in Nepal

Shah, A., \& Shah, S. (2006). The new vision of local governance and the evolving roles of local governments. In A. Shah (Ed.), Local governance in developing countries (pp. 1-50). Washington, D.C.: The World Bank.

Shapiro, S. S., \& Wilk, M. B. (1965). An analysis of variance test for normality (complte samples). Biometrika , 52 (3/4), 591-611.

Sreejech, S., Mohapatra, S., \& Anusree, M. R. (2014). Business research methods: An applied orientation. Springer International Publishing, Switzerland.

Subedi, S. L. (2014). Fiscal decentralization in Nepal: A municipal perspective. New Delhi: Adarsha Book.

Sepulveda, C. F., \& Martinez-Vazquez, J. (2010). Consequences of fiscal decentralization on poverty and income equality. Environment and Planning C: Government and Policy, 321-343.

The World Bank. (2000). Entering the 21st century: World development report 1999/2000. Washington, D.C.: The World Bank.

The World Bank. (2013). Localizing development: Does participation work. Washington D.C. : The World Bank.

Tiebout, C. (1956). A pure theory of local expenditure. Journal of Political Economy , 64 (5), 416-24.

Vista-Baylon, H. I. (2001). Decentralization: What, when, and how. In S. Schiavo-Campo, $\&$ P. Sundaram (Eds.), To serve and to preserve: Improving public administration in a competitive world. Manila 2001: Asian Development Bank.

Weingast, B. R. (1995). The economic role of political institutions: Market-preserving federalism and economic development. The Journal of Law, Economics, \& Organization, 11 (1), 1-31.

Yamane, T. (1967). Statistics: An introductory analysis (2nd ed.) New York, NY: Harper and Row. 
Fiscal Decentralization and Municipal Performance in Nepal

Annex A: Indicators for municipal performance measures Indicators

1. Formulation of participatory annual development plan Scores

2. Allocation of budget and programme to women, children and socio- 2 economic backward community

3. Spending of targeted programme budget to the benefit of women, children 2 and socio-economic backward community

4. Allocation and spending of budget for child protection and development 2 and adoption of child-friendly local governance

5. Information management through the information centers, information 4 disclosures on the website, compliance of rights to information, execution of GIS on development projects and monthly disclosures of income and expenditures

6. Transparent and effective management of social security programme 2 through the disclosure of information and updated data-base management

7. Preparation and timely submission of monthly and yearly physical and 2 financial progress report

8. Conducting the public hearing on quarterly basis 2

9. Feasibility study on revenue potentialities and projection of annual 2 revenues based on the study

10. Consistency between actual and projected income and expenditure and 4 their implementation

11. Management of revenue administration with due process and maintain of 4 electronic records

12. Revenue enhancement through enforcement of integrated property tax 2

13. Adoption of public-private partnership modality in municipality 2

14. Compliance with optimum limitation of administrative expenses 2

15. Adoption of accrual accounting system 2

16. Management of security deposit accounts in accordance law 2

17. Quality of financial transactions: Management of accounts and advances 2 
Fiscal Decentralization and Municipal Performance in Nepal

\begin{tabular}{|c|c|}
\hline Indicators & Scores \\
\hline 18. Compliance of limitations of expenses on financial administration & 2 \\
\hline 19. Local resource mobilization & 4 \\
\hline $\begin{array}{l}\text { 20. Implementation of municipal plan: Periodic plan, municipal transportation } \\
\text { master plan, and preparation of municipal profile }\end{array}$ & 2 \\
\hline $\begin{array}{l}\text { 21. Pre-feasibility and feasibility study of development projects in accordance } \\
\text { with the provisions of Local Self-Governance Act, } 1999\end{array}$ & 2 \\
\hline $\begin{array}{l}\text { 22. Procurement Management: Preparation and enforcement of procurement } \\
\text { plan and e-submission system }\end{array}$ & 4 \\
\hline $\begin{array}{l}\text { 23. Final clearance and technical settlement of completed development } \\
\text { projects and their approval form municipal council }\end{array}$ & 2 \\
\hline 24. Project inventory profile and provision of maintenance and repair fund & 4 \\
\hline 25. Transparency in project management & 2 \\
\hline $\begin{array}{l}\text { 26. Implementation of monitoring and evaluation system in accordance with } \\
\text { law }\end{array}$ & 2 \\
\hline 27. Enforcement of social accountability system & 2 \\
\hline 28. Enforcement of employees' job description & 2 \\
\hline 29. Service management through citizen charter and other by-laws & 2 \\
\hline 30. Provision of employee welfare fund & 2 \\
\hline 31. Lawful enforcement of service contract system & 2 \\
\hline 32. Enforcement of code of conduct property disclosure system & 2 \\
\hline 33. Sanitation and solid waste management & 4 \\
\hline 34. Environment management & 4 \\
\hline 35. Vehicle parking management & 2 \\
\hline 36. Management of slaughtering houses and meat shop & 2 \\
\hline 37. Public health promotion & 2 \\
\hline 38. Emergency service and disaster management & 4 \\
\hline 39. Vital registration management & 2 \\
\hline 40. Enforcement of building by-laws and building code & 2 \\
\hline Total Scores & 100 \\
\hline
\end{tabular}


Fiscal Decentralization and Municipal Performance in Nepal

\begin{tabular}{lc}
\hline \multicolumn{1}{c}{ Indicators } & Total Score \\
\hline 41. Sanitation and solid waste management & 4 \\
42. Environment management & 4 \\
43. Vehicle parking management & 2 \\
44. Management of slaughtering houses and meat shop & 2 \\
45. Public health promotion & 2 \\
46. Emergency service and disaster management & 4 \\
47. Vital registration management & 2 \\
48. Enforcement of building by-laws and building code & 2 \\
\hline
\end{tabular}

Annex B: Sampling structure of the study

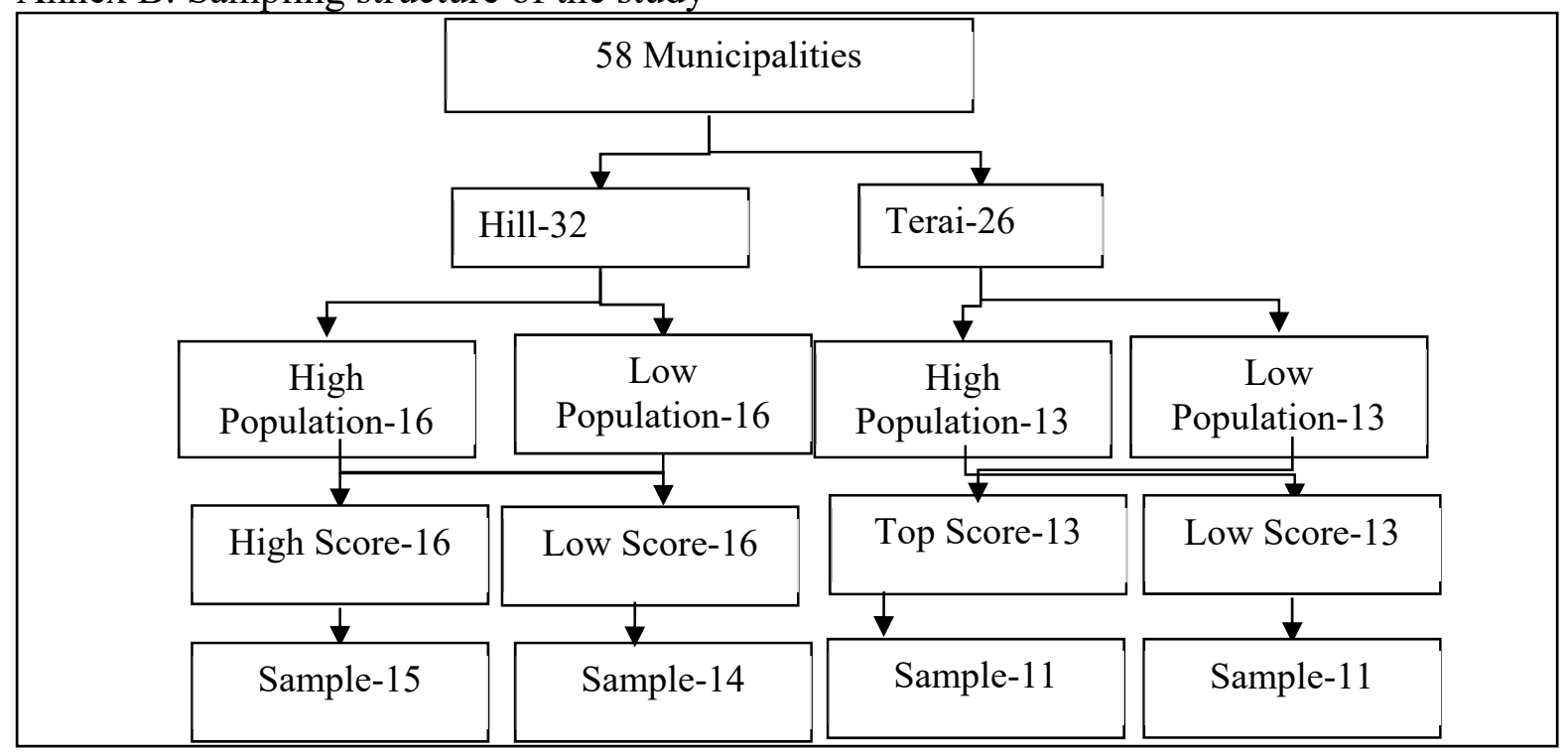

